\title{
EVOLUTION OF EUROPEAN GM-FREE STANDARDS: REASONING OF CONSUMERS AND STRATEGIC ADOPTION BY COMPANIES
}

\author{
Thomas J. VENUS*1, Justus H.H. WESSELER ${ }^{1}$
}

\begin{abstract}
Address:
${ }^{1}$ Wageningen University, Agricultural Economics and Rural Policy Group, Economics Department, Hollandseweg 1, 6706 kn Wageningen, The Netherlands, phone: +31 317482097

*Corresponding author: thomas.venus@wur.nl
\end{abstract}

\begin{abstract}
In this article, we discuss reasoning of consumers and strategic adoption behavior of producers and retailers with respect to genetically modified-free (GM-free) quality standards in Europe. We argue that there are three major reasons why a mandatory GM labeling scheme differs from a voluntary process-based GM-free labeling scheme regarding the effect on consumer demand: (1) while both mandatory and voluntary labels signal that products containing, or produced with genetically modified organisms (GMOs) are of lower quality, experiments show that the signaling effect is stronger in the case of mandatory labels; (2) some consumers care more about the effects of consuming GMOs directly (i.e., labeled GMO) compared to consuming only products derived from GMOs (i.e., nonlabeled GM-free); and (3) mandatory labeling shifts some of the labeling burden to the GM producer making the GM product relatively more expensive compared to the case of voluntary GM-free labeling. We discuss reasons why producers or retailers set or implement a voluntary GM-free production standard. To illustrate how the firm adoption theory can be extended, we use a real option game framework in a duopolistic setting and show that it can be beneficial to offer a GM-free product without labeling it. We show that this can be the case if investing without labeling works as a pre-investment or option to extend to reduce the investment cost of implementing a label in the case of an increase in demand. Finally, we provide a list of important events that have affected the evolution of the GM-free market in Europe.
\end{abstract}

Keywords: private quality standards, voluntary label, GM-free, GMO, real option game JEL: L15, L22, Q13

\section{GM-FREE LABELING IN THE EUROPEAN UNION AND IN THE UNITED STATES}

Labeling of genetically modified (GM) food products remains a hot topic in the European Union, and it has been a prominent topic over the last few years in the United States, too. Food, biotech, and other firms spent large amounts of money in referenda in some US states (e.g., Proposition 37 in California) for or against mandatory labeling. In California, at the end 51.5 percent of the voters decided against mandatory labeling, and hence the proposition failed. Zilberman et al. (2014) show that a large share of voters only decided to vote against mandatory labeling after campaigners had published estimates of potential price increases of food products.

In the European Union, the labeling situation is different to the US policy. A mandatory GMO label has already been in place since the early 2000s. Additionally, and this is the main focus of this article, firms in some EU Member States may label their products as GM-free by following private or public production standards, like the exclusion of GMOs from the process of food or feed production.

GM-free standards in the European Union may be classified as voluntary public standards if an EU Member
State sets the standard within a legal legislation, or as voluntary private standards, if set by private entities (e.g., retailers) (Henson and Humphrey, 2010). A report by the European Commission (2015) shows that national government policies either facilitate GM-free labeling (e.g., in Germany, France, and Austria), allow GM-free labeling under highly restrictive circumstances (e.g., in the Netherlands, Switzerland, and Finland), or prohibit GM-free labeling (e.g., in Belgium and Sweden). The motivation in the first case is to provide a choice to consumers and producers, while in the other cases the motivation is to avoid consumers' confusion or misleading information (European Commission, 2015). In several countries, firms have set private standards for GM-free labeling (e.g., COOP in Italia or Carrefour in France). Additionally, some retailers require or required unlabeled GM-free production from their suppliers (e.g., LIDL or ALDI in Germany) (Wesseler, 2014).

In this paper, we discuss the evolution of the GMfree market from a consumer and a producer perspective. Based on recent literature, we discuss how consumers respond to labeling and why and how private operators respond to the introduction of labeling options. We also explain firms' private standard adoption without labeling. We provide a list of events and actors driving the GMfree adoption and intuitively explain the decision process 
of retailers and processors. Further, we discuss how the different drivers may have influenced the adoption of voluntary GM-free labeling standards in some EU Member States.

\section{LABELING IN THE EUROPEAN UNION AND CONSUMER ACCEPTANCE}

\section{Mandatory vs. voluntary labeling}

In the European Union, all food and feed products that contain more than 0.9 percent EU-approved GMOs must be labeled as GMO to comply with the Regulation (EC) 1829/2003. The Regulation excludes labeling of animal products derived from animals fed with GM-feed; hence retailers can still sell products of GM-fed animals without a GMO label (similar to the United States). To enable consumers the choice to buy animal products derived from animals fed with non-GM feed, some EU Member States adopted national GM-free schemes for voluntary labeling animal products. Retailers and producers can label their food products as GM-free by ensuring that each party of the supply chain - seed suppliers, farmers, handlers, and processors - only uses non-GM inputs (Venus et al., 2012).

The EU and US labeling schemes differ with respect to labeling of GMOs, but share commonalities with respect to the use of GMOs in the production process. First, both countries do not have mandatory labeling standards for products derived from animals fed with GM-feed. Second, all organic labeling schemes in both countries prohibit any use of GMOs in both food and feed products and the animal production process. A difference between organic labels in the United States and the European Union is that the USDA organic label allows adventitious presence, whereas the EU organic label does not (see Beckmann, Sorregaroli and Wesseler, 2011). What some EU Member States define nationally as a GM-free standard is therefore already, to some extent, covered by the organic standard, although the organic standard has additional demands such as the prohibition of a number of pesticides in crop production or higher requirements of minimum space per livestock unit.

The signal of GM-free labels has implications for conventional as well as organic processors. Since consumers are often imperfectly informed about the production standards of labels (e.g., Kubitzki et al., 2010), organic producers may also use the GM-free label to highlight the GM-free status as some do, for example, in Germany (Punt et al., forthcoming).

\section{Difference of labeling schemes for consumers}

There are three major reasons why a mandatory GM labeling scheme differs from a voluntary GM-free labeling scheme with respect to the effect on consumer demand: (1) while both mandatory and voluntary labels signal that GMOs are of lower quality, experiments show that the signaling effect is stronger in the case of mandatory labels; (2) some consumers care more about the effects of consuming GMOs directly (i.e., labeled GMOs) compared to consuming only products derived from GMOs (i.e., non-labeled GM-free); and (3) mandatory labeling shifts some of the labeling burden to the GM producer, making the GM product relatively more expensive compared to the case of voluntary GMfree labeling. Next, we discuss these three points in greater detail.

Applying Spence's (1973) idea of signaling, one might expect that a GMO labeling signal is just the opposite of the signal of a GM-free label; that is, a GMO label signals that all non-labeled products are GM-free and vice versa. Only firms that can provide GM-free products under a mandatory labeling scheme costefficiently would exclude the GMO label. Empirical studies, however, show that the signal of the absence of a GM-free label differs from the signal of a GMO label. In particular, Costanigro and Lusk (2014) found that consumers' willingness to pay to avoid GMOs in the case of a "contains" label was significantly higher than in the case of a "does not contain" label. The results of Costanigro and Lusk (2014) indicate that the signals to the consumers that GMOs are of low quality or should be avoided are larger for "contains" labels than for "does not contain” labels. Similarly, Liaukonyte et al. (2013) find that the negative effect of the "contains X" label significantly exceeds the positive effect of a "does not contain X" label when consumers have negatively framed information about X. Liaukonyte et al. (2013) further show that due to information asymmetries, consumers are unable to credibly evaluate the label.

There are at least two reasons why some consumers reject GMOs: (1) beliefs about direct effects from consuming GMOs, such as effects on human health; and (2) beliefs about indirect effects from buying GMOs, such as effects on market structure, animal health and the environment (e.g., Winston, 2002; Moses and Brookes, 2013). Other concerns might be direct and indirect, such as ethnical, philosophical, or religious beliefs (Gaskell et al., 2010). On the one hand, if European consumers were concerned only about direct effects, it would be rational only to reject products containing GMOs and to accept products processed with GMOs. On the other hand, if consumers were concerned only about indirect effects, they should equally reject mandatorily labeled GM products and animal products without the GM-free label. The rejection based on direct or indirect effects strongly depends on how well consumers are informed. Kubitzki et al. (2010) show that German consumers who participated in a survey were neither well informed about the message of GM-free labels, nor about GMOs in general. Additionally, the authors show that expectation of the GM-free label differed substantially from the actual label requirements. Some consumers may also be misled by believing that the GM-free label refers to the absence of GMOs in the product rather than the absence of GMOs in the production process (e.g., animal feeding), or that the animal itself, from which the final product is derived, is not genetically modified (European Commission, 2015).

Another reason for demand effects due to differences in the type of labeling scheme is the relatively higher price of GMOs under mandatory labeling. Providers of high quality credence products (here, the GM-free producer) have to recoup the labeling 
cost. High quality providers need to make sure that all requirements are fulfilled to allow them to label their product as GM-free. These costs may include costs of segregating GM and non-GM products, monitoring and control, or certification to preserve the identity of the GM-free product along the whole supply chain. Labeling costs may partly be shifted either to the taxpayer or, through mandatory labeling, to the GM producer (Carter and Gruére, 2003; Zilberman et al., 2014). Shifting some of the labeling costs increases the price of GM products, ceteris paribus.

\section{GM-FREE LABELING STRATEGIES OF PRODUCERS AND RETAILERS}

Various actors can set production standards. Some EU Member States have defined legal minimum requirements for GM-free labeling. Based on these minimum requirements, non-governmental organizations (NGOs) or single actors in the industry can implement their own labeling schemes. Some firms may also provide GM-free products following (or not) the minimum standard but without labeling. In the following, we discuss some incentives of firms to adopt production standards and illustrate firms' strategic adoption behavior.

\section{Why firms set private voluntary production standards}

Retailers may set private standards for several reasons. Vigani and Olper (2014) show that the reasons are often based on historical factors, communication infrastructure, and sectorial conditions. Vandemoortele and Deconinck (2014) provide an overview based on previous literature and list mainly strategic reasons. We discuss these reasons in relation to GM-free production.

(1) Communicating product attributes to facilitate firm matching

GM-free product providers need to find suppliers that offer GM-free inputs. If suppliers are certified and label their product, downstream buyers are less uncertain about the product quality.

(2) Vertical product differentiation to soften price competition

First-generation GM products, that is, products that are mainly designed to benefit the crop cultivation, are usually modeled as vertically differentiated. Firms that offer GM-free products can differentiate their products from conventional products and ask a price premium.

(3) Improving bargaining power over suppliers In a game theoretic model, Von Schlippenbach and Teichmann (2012) show that downstream retailers with market power are able to increase their bargaining power over upstream suppliers by setting private standards. Upstream suppliers need to make specific investments to switch from conventional to GM-free production. If suppliers switch to comply with a retailer standard and no other retailer offers GM-free retail brands, then the supplier only has the option to supply the GM-free retailer or to exit the GM-free market. In the case where other retailers also offer GM-free retail brands one of them may offer an even higher standard to bind their suppliers more strongly.
(4) Preempting government regulations to weaken public standards

McCluskey and Winfree (2009) argue that private firms' preemption lets the firm decide the standards and stringency the firms prefer before governments set the standards. As Fischer and Lyon (2014) point out, NGOs usually want to set higher standards than the industry. However, the dilemma is that the stricter a standard, the less are firms able to adopt it cost-efficiently, whereas less strict standards may not be in line with consumers' expectations of the "GM-free" claim (Kubitzki et al., 2010). If consumers cannot distinguish stringencies of labels set by different parties, then label competition will force the standard to be set at the minimum requirement (Fischer and Lyon, 2014; Bonroy and Constantatos, 2014). While small producers may lobby for lower public standards, intermediaries (e.g., retailers) may use its market power to impose a higher private standard (Vandemoortele and Deconinck, 2014).

\section{An illustration of firms' strategic adoption decisions using option games}

Producers and retailers set and implement private standards strategically, that is, when making their decision, they also take into account the decision of other firms. Game theory offers theoretical models to analyze strategic behavior. However, standard models in game theory do not consider a possibility that firms give up flexibility when they make sunk investments. Once a firm implements a GM-free label, it cannot undo the investments made and may even face some additional burden such as reputation damage when exiting the GMfree market (Punt et al., forthcoming). Therefore, it can be costly to enter the new market too early since the demand for GM-free products may decrease in the future before the investment costs are recovered. Often, it pays to wait and only invest if the present value is high enough to cover the necessary investment cost. A simple net present value (NPV) calculation considers only expected costs to decide whether to invest today or not, but neglects the value of flexibility, or the option to wait.

Another strategy can be to make a small first-stage investment such as an agreement with suppliers to produce GM-free but not to label the product. This agreement provides the strategic option to invest in labeling "earlier" (in terms of threshold values) as compared to the absence of an agreements. The firm will only exercise the option when GM-free demand increases. Again, a simple NPV calculation may result into the rejection of such a retailer standard, because it neglects the value of extending the GM-free agreement by labeling.

When more than one firm exists on the market, and all firms have the option to invest or the option to extend, a trade-off between the value of flexibility and the value of committing must be made. Real option games-a combination of real options and game theory-provide a tool to model this trade-off.

Assume two firms, denoted by $i$, one with low $(L)$ and one with high $(H)$ costs. Firms face a linear stochastic inverse demand function for GM-free products 
with parameters $a$ and $b$, quantities $q_{i}$ with $i=L, H$ and a stochastic process parameter $\tilde{X}_{t}$

$$
p\left(\tilde{X}_{t}, q_{L}, q_{H}\right)=a \tilde{X}_{t}-b\left(q_{L}+q_{H}\right) .
$$

Parameter $\tilde{X}_{t}$ follows a multiplicative binomial process; that is, the value in each following period can either go up by $u$ or down by $d=1 / u$. Assume a cost function $C_{i}\left(q_{i}\right)=c_{i} q_{i}$ and per period profit $\pi_{i}^{k}\left(q_{i}, q_{j} \tilde{X}_{t}\right)=\left[p\left(Q, \tilde{X}_{t}\right)-c_{i}\right] q_{i}$, where Index $k=M, C$ denotes whether one firms invests in GM-free labeling and gets monopoly profits $\left(\pi_{i}^{M}\right)$, or both firms invest and get Cournot profits $\left(\pi_{i}^{C}\right)$. Applying the idea of focal point theory, we assume that either only the low-cost firm or both firms invest, but never the high-cost firm alone. If only the low cost firm invests, it receives monopoly profits

$$
\pi_{L}^{M}\left(\tilde{X}_{T}\right)=\frac{\left(a \tilde{X}_{t}-c_{L}\right)^{2}}{4 b}
$$

If both firms invest, they determine their optimal quantity through Cournot quantity competition and receive profit

$$
\pi_{i}^{C}\left(\tilde{X}_{T}\right)=\frac{\left(a \tilde{X}_{t}-2 c_{i}+c_{j}\right)^{2}}{4 b}, \quad \text { where } i \neq j
$$

Consider a duopolistic setting where firm $i$ needs to decide in two stages. In the first stage, the firm can chose one of three decisions:

(1) Option to invest: continue offering conventional (GM) products at $t=0$ and decide whether to invest in a label in stage two;

(2) Option to expand: make a GM-free agreement with non-zero investment cost at $t=0$ without labeling and decide whether to invest in a label in stage two; or

(3) Invest immediately: implement GM-free standard and label at $t=0$ until infinity, if the NPV is equal to or above the larger value of the investment and expansion option.
In the second stage, a firm may have already decided to label at $t=0$. If so, it does not need to make any decision at stage two. If the firm decided to continue conventional production (decision 1) or to make a GMfree agreement without labeling (decision 2), it will invests in a label at time $T$ only if its value exceeds some threshold. Depending on the decision in stage one, it faces investment costs:

(a) $I_{i}^{G}$, where $G$ denotes that the firm chose to continue to offer conventional (GM) products in stage one; or

(b) $I_{i}^{N}$, where $N$ (for Non-GM input) denotes that the firm made an GM-free agreement without labeling in stage one;

and $I_{i}^{N}<I_{i}^{G}$. Since the GM-free agreement involves stage one investment costs, firms need to deduct this cost from the value of the extension option.

Firms need to make their first stage decision, knowing their strategy set and payoffs of the second stage. Therefore, the game needs be solved backwards, starting with stage two.

In the second stage, firms can decide whether or not they continue their choice at stage one of conventional production or to exercise the investment or the expansion option. Each firm's decision depends also on the decision of the other firm.

At $t=1$ the net present value $N P V_{i, 1}^{k, h}$ of firm $i$ is the difference between its present value $V_{i, 1}^{k}\left(\tilde{X}_{T}\right)$ and its irreversible cost $I_{i}^{h}$

$$
\begin{gathered}
N P V_{i, 1}^{k, h}\left(\tilde{X}_{T}\right)=\frac{\pi_{i}^{k}\left(\tilde{X}_{T}\right)}{\delta}-I_{i}^{h} \\
\quad \text { for } k=M, C \text { and } h=N, G,
\end{gathered}
$$

where $\delta$ is the opportunity cost of waiting. Only if at time $T, \tilde{X}_{T}$ is equal to or above some threshold should the low-cost firm invest (if $X_{L}^{M} \leq \tilde{X}_{T} \leq X_{i}^{C}$ ) or both (if $\left.\tilde{X}_{T} \geq X_{i}^{C}\right)$, where $X_{i}^{k}$ solves $N P V_{i}^{k, h}\left(\tilde{X}_{T}\right)=0$. This is, because at $\mathrm{T}$, the option expires and the NPV rule holds.

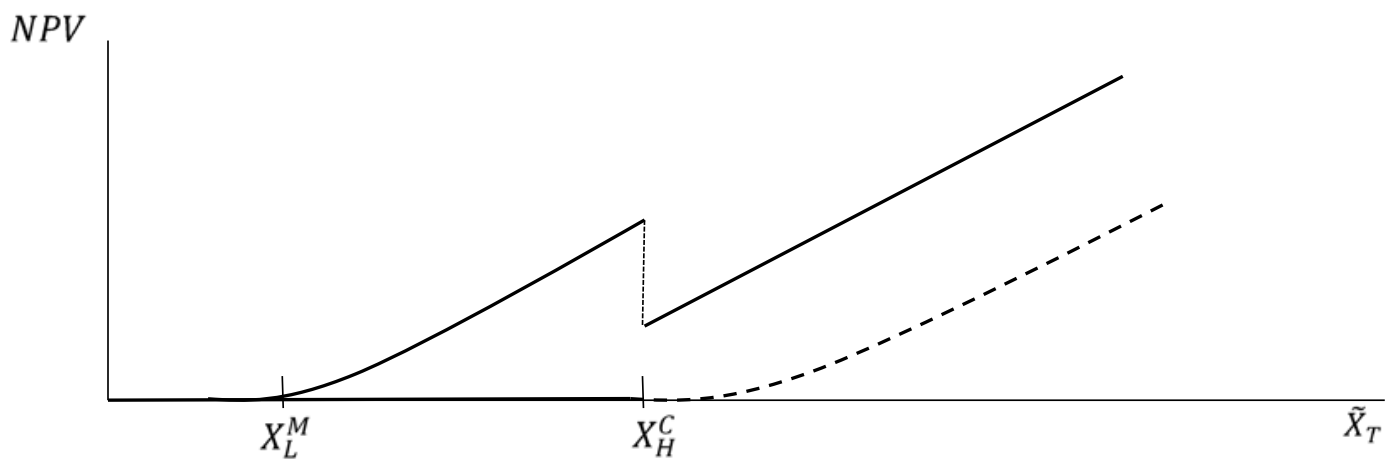

Figure 1 Net present value (NPV) as a function of stochastic demand parameter, $\tilde{X}_{T}$, and investment option threshold values of the low cost $\left(X_{L}^{M}\right.$, solid line) firm and the high cost $\left(X_{H}^{C}\right.$, broken line) firm. (Adopted from ChevalierRoignant and Trigeorgis (2011)) 
Figure 1 shows the NPV evolution and investment thresholds under monopoly and Cournot duopoly. At the point where $X_{H}^{C}$ is reached, the high cost firm will invest and the value of the leader firm will make a drop, because when $\tilde{X}_{T} \geq X_{H}^{C}$, firms need to share the quantity demanded.

\section{Evolution of voluntarily labeled GM-free products}

The evolution is very diverse in different countries and in general much slower and less intense than retailers' GMO ban of after mandatory labeling.

Austria was the first EU Member State to implement a directive for defining GM-free production in 1998 (Federal Ministry of Austria, 2010). In 2008, the German Genetic Engineering Act of 1990 was revised (Federal Ministry of Germany, 2004). Since then, GMfree labeling is no longer based on the regulation for novel food products (NLV) of 1998. The new regulation, similar to the Austrian scheme, is less strict than the NLV. In 2012, France adopted a new legislation on GMfree production with GM-thresholds for GM-free labels; the threshold is either 0.1 or 0.9 percent adventitious presence of GMOs in animal feed, depending on the type of label (Répubique Francaise, 2012).

Labeling schemes in Finland and the Netherlands are strict and prohibit any GMOs in the feed. Labeling schemes in Austria, France and Germany allow adventitious presence of GMOs up to a threshold and farmers can feed GMOs for a specified time period. The non-GM feeding times vary by country (European Commission, 2015). Poultry must be fed with non-GM feed three days after birth in Austria and France, while it is sufficient in Germany to feed non-GM feed starting 10 weeks before slaughter. Pigs require to be fed non-GM feed for the total fattening period in Austria and 4 or 4.5 month before slaughtering in Germany or France, respectively. The minimum non-GM feeding before milking is 2 weeks in Austria, 3 months in Germany, and 6 month in France. The feeding period is 6 weeks before laying eggs in all three countries. GM feed additives like vitamins, amino acids, or enzymes are also allowed. Additionally, GM medicinal products or vaccines can be used to treat animals. However, some of the country- and animal-specific thresholds substantially contradict what consumers expect from the label (Kubitzki et al., 2010).

While Austria, France, Germany, and the Netherlands specify the words that must be used for labeling, Austria and Germany also provide a nonprescriptive logo. If firms, for example, in Germany want to use the non-prescriptive logo they need to comply with the rules of the licenser. In addition, firms may also adopt their own logo. The minimum requirement a firm has to comply with, independently of the logo, is the national regulation or guideline.

In countries that do not have GM-free regimes (e.g., the UK, Slovenia, the Czech Republic, Poland, Spain), some retailers developed their own private standard (Moses, 2012). Belgium, Sweden, and Switzerland prohibit the wording "GM-free" but the Swiss retailers COOP and Migros publicly state to use no GM feed derived livestock products.
Without minimum threshold levels it is hardly feasible to offer GM-free labeled products. This is documented by some anecdotal evidence from a German dairy (Upländer Bauernmolkerei) that started to offer GM-free labeled milk in 2005, before the revision of the Genetic Engineering Act. The dairy emphasized the difficulties in fulfilling all requirements under the strict regulations during that time, which entailed high costs and fraught with uncertainties on legal requirements (Gen-ethisches-Netzwerk, 2006). Shortly after the introduction of the label, the dairy exited the GM-free market again.

GM-free schemes of some countries allow labeling of non-animal food products. The German scheme allows GM-free labeling of non-animal food, if adventitious presence of GMOs is below 0.1 percent-only if the product contains a source of potential GMcontamination. Additionally labeling must comply with the regulation on self-evident advertising, which prohibits the use of a GM-free label when consumers can expect the product to be naturally GM-free. Whether a GM-free claim is self-evident or not needs to be decided on a case by case basis. The governmental food inspection in Germany, for example, decided that Oettinger, the brewery of the most consumed German beer brand, is allowed to label their beer as GM-free, if all ingredients contain less than 0.1 percent adventitious presence of GMOs (Spelsberg, 2013). The German brewery association heavily criticized the decision by Oettinger, claiming that GM-free labeling of beer deceives consumers (Spelsberg, 2013). Consumers in Germany may now be faced with three types of beer: labeled as "Contains GMOs", if it was produced, for example, with GM maize; without a label, if all ingredients contain less than 0.9 percent adventitious GMOs; or with a GM-free label, if breweries comply with the GM-free standard. At present, only unlabeled beer or beer with a GM-free label are available in Europe.

\section{GM-free label implementation of retailers}

Over the last decade, several retailers have adopted GMfree labels for their retail brands. In Austria, according to ARGE (2013), almost all milk and eggs are GM-free. In Germany, about 50 percent of eggs and somewhat less than 10 percent of milk is produced following the national GM-free standard (VLOG, 2015). In France, as of 2010-2011 Carrefour is the major GM-free producer with about 70 percent GM-free produced pork (Lebensmittelzeitung, 2010). Pork production requires a lot of protein feed and hence, this share is rather large for pork. In a survey, Passuello et al. (2013) show that the largest Italian retailer produces about 100 percent of its privately-labeled poultry, eggs, and milk as well as 50 percent of cold cut meat, cheese, and ham as GM-free. In Switzerland, imports of GM feed are entirely banned and the two major retailers “...systematically ban all GM food, including meat, poultry, and dairy produce from livestock fed on GM feed in their supermarket brands." (GMO-free Regions, 2013).

It is difficult to judge from market observations if retailers are setting private standards to preempt 
governmental standards. However, in Germany preemption of retailers would hardly be possible because until the new labeling standard was implemented in the GM engineering act in 2008, GM-free production was nearly infeasible due to its strictness and lack of threshold values. After loosening the standard, mainly small firms implemented the GM-free label, followed by larger firms, but mainly after being pressured by NGOs (Greenpeace, 2008). This is similar to the situation in Austria. In France and Italy, for example, retailers seemed to have been the driving forces to implement private labeling schemes.

The major retailers in the UK agreed upon reliably produced GM-free poultry and eggs until all retailers (except for Waitrose) abandoned the GM-free policy in 2012-2013 (GM Freeze, 2013). The systematic announcement of UK retailers to exit the GM-free market indicates that exiting the GM-free market, once a critical mass has been reached, can also be a strategic complement. If all retailers exit the market at the same time, NGO attacks are less effective and so one retail exit benefits the exit of all other retailer, because if all or most retailers make the same decision, consumers can hardly substitute among retailers. Tesco PLC, the largest UK retailer leaded this exit. The largest retailer leaving the GM-free market first supports the theory that smaller firms can survive longer in markets with shrinking demand (e.g., Ghemawat and Nalebuff, 1985). A similar situation occurred in Germany, when the central association of poultry production announced its GM-free market exit in 2014 as a group (instead of each firm exiting individually) (ZDG, 2014). However, the environmental NGO Greenpeace strongly attacked the largest producer of the association, Wiesenhof. This attack made Wiesenhof to convert back to GM-free.

Two German discounters (ALDI and LIDL) made GM-free agreements with their suppliers without labeling the final product. Using the idea of real option theory, as shown above, those discounters had the option of implementing the label in case of a demand increase and exiting the marked otherwise. When two other major retailers announced they would soon implement the GMfree label, ALDI and LIDL implemented the GM-free label soon after the announcement of their competitors (VLOG, 2015).

\section{CONCLUSION}

Several EU Member States have introduced GM-free labeling legislations and guidelines. While some labeling schemes facilitate GM-free labeling (e.g., in Austria, Germany, and France), other schemes in other countries (e.g., in the Netherlands, Finland) are very strict or do not allow GM-free labeling at all (e.g., in Belgium, Sweden). The implementation of GM-free labels (i.e., the provision of products processed without GMOs) went much slower than the "ban" of mandatory labeled products (i.e., products containing GMOs) from retail shelfs. From consumers' side, we argue that this may have three major reasons. First, a mandatory GMO label as well as a voluntary GM-free label signals that GMOs are unsafe, but the effect of mandatory labels is stronger for imperfectly informed consumers. Second, some consumers care more about the effects of consuming GMOs directly (i.e., labeled GMO) compared to consuming only products derived from GMOs (i.e., nonlabeled GM-free). Third, mandatory labeling makes GM products relatively more expensive compared to voluntary labeling. The signaling and the cost effect indicate that if animal products were mandatorily labeled, it would lead to less provision of animal products derived from GM-fed animals.

Different reasons can explain producer and retailers' strategic behavior when adopting GM-free standards or setting private labeling schemes. Literature as well as strategies chosen by food processors and retailers show the presence of strategic behavior. Using option games, we were able to show that it can be beneficial to produce GM-free without labeling, not only if its current profits are positive, but also if GM-free production lowers the investment threshold for labeling in the following periods. If this is the case, GM-free production without labeling can be considered as an option to expand and may explain why some retailers, in addition to other strategic reasons, have chosen that strategy.

Acknowledgments: The research leading to these results has received funding from the European Union's Seventh Framework Programme (FP7/2007-2013) under grant agreement no. KBBE-2011-5-289157.

\section{REFERENCES}

ARGE, 2013. Hersteller \& Handel Gentechnik-freier Lebensmittel. Available at: http://www.gentechnikfrei.at/ BECKMANN, V., SOREGAROLI, C. and WESSELER, J. (2011). Coexistence of genetically modified (GM) and non-modified (non GM) crops: Are the two main property rights regimes equivalent with respect to the coexistence value? In C. Carter, G. Moschini, I. M. Sheldon (eds), Genetically modified food and global welfare. Bingley: Emerald Group Publishing, 201-224.

BONROY, O. and CONSTANTATOS, C. 2014. On the economics of labels: how their introduction affects the functioning of markets and the welfare of all participants. American Journal of Agricultural Economics. 97, (1). 239-259. doi: 10.1093/ajae/aau088>

CARTER, C.A. and GRUÈRE, G.P. 2003. Mandatory labeling of genetically modified foods: does it really provide consumer choice?. Agbioforum. 6, (1\&2). 68-70. CHEVALIER-ROIGNANT, B., and TRIGEORGIS, L. 2011. Competitive strategy: Options and games. MIT Press.

COSTANIGRO, M. and LUSK, J.L., 2014. The signaling effect of mandatory labels on genetically engineered food. Food Policy. 49, (1), 259-267. doi: 10.1016/j.foodpol.2014.08.005>

EUROPEAN COMMISSION. 2015. State of play in the EU on GM-free food labelling schemes and assessment of the need for possible harmonisation. Final report. DG SANCO. Written by ICF GHK in association with ADAS, Ltd. doi: 10.2875/4437>

FEDERAL MINISTRY OF AUSTRIA 2010. Richtlinie zur Definition der "Gentechnikfreien Produktion" von 
Lebensmitteln und deren Kennzeichnung, Österreichs Lebensmittelbuch, IV. Auflage, Bundesministerium für Gesundheit. Available

at:

https://www.verbrauchergesundheit.gv.at/lebensmittel/bu ch/codex/beschluesse/gentechnikfreie_produkte.html>

FEDERAL MINISTRY OF GERMANY 2004. EGGentechnik-Durchführungsgesetz vom 22. Juni 2004 (BGBl.|S.1244), das zuletzt durch Artikel 2 des Gesetzes vom 9. Dezember 2010 (BGBl.|S.1934) geändert worden ist. EGGenTDurchfG der Bundesregierung. Available at: http://www.gesetze-im-

internet.de/bundesrecht/eggentdurchfg/gesamt.pdf>

FISCHER, C. and LYON, T.P. 2014. Competing environmental labels. Journal of Economics \& Management Strategy. 23, (3). 692-716. doi: 10.1111/jems.12061>

GASKELL, G., STARES, S., ALLANSDOTTIR, A., ALLUM, N., CASTRO, P., ESMER, Y., FISCHLER, C., JACKSON, J., KRONBERGER, N., HAMPEL, J., MEJLGAARD, N., QUINTANILHA, A., RAMMER, A., REVUELTA, G., STONEMAN, P., TORGERSEN, H. and WAGNER, W. 2010. Europeans and Biotechnology in 2010: Winds of change?. Report to the European Commission's Directorate-General for Research, Eurobarometer 2010.

GEN-ETHISCHES-NETZWERK 2006. Milch ohne Gentechnik - geht das? Interview von Christof Potthof. Available at: http://www.gen-ethischesnetzwerk.de/gid/176/milch-ohne-gentechnik-geht>

GHEMAWAT, P. and NALEBUFF, B. 1985. Exit. The RAND Journal of Economics. 16, (2); 184-194. Stable URL: http://www.jstor.org/stable/2555409>

GM FREEZE 2013. Get hidden GM out of your trolley. GMO-FREE REGIONS 2013. GMO-Free retailers by country. Available at: http://www.gmfreeze.org/>

GREENPEACE 2008. Greenpeace-Erfolg: Landliebe ohne Gentechnik, Hamburg. Available at: https://www.greenpeace.de/themen/gentechnik/greenpea ce-erfolg-landliebe-ohne-gentechnik>

HENSON, S. and HUMPHREY, J. 2010. Understanding the complexities of private standards in global agri-food chains as they impact developing countries. The Journal of Development Studies. 46, (9). 1628-1646. doi: 10.1080/00220381003706494>

KALAITZANDONAKES, N. and BIJMAN, J. 2003. Who is driving biotechnology acceptance? Nature Biotechnology. 21, 366-369. doi: 10.1038/nbt0403-366> KUBITZKI, S., HENSELEIT, M. and HERRMANN, R. 2010. Informationsgewinn und Markttransparenz durch Labeling? - Eine kritische Würdigung der neuen Lebensmittelkennzeichnung „ohne Gentechnik“. Schriften der Gesellschaft für Wirtschafts-und Sozialwissenschaften des Landbaus eV Band 45, 213.

LEBENSMITTELZEITUNG 2010. Carrefour: Setzt Zeichen, Lebensmittelzeitung. Available at: http://www.lebensmittelzeitung.net/login/login.php?fg=1 \&url=http\%3A\%2F\%2Fwww.lebensmittelzeitung.net $\% 2$ Fnews\%2Fmarkt\%2Fprotected\%2F-Setzt-

Zeichen 83395.html>

LIAUKONYTE, J, STRELETSKAYA, N.A., KAISER, H.M. and RICKARD, B.J. 2013. Consumer response to “Contains” and "Free of” labeling: evidence from lab experiments. Applied Economic Perspectives and Policy. 35, (3), doi: 10.1093/aepp/ppt015>

MCCLUSKEY, J.J. and WINFREE, J.A. 2009. Preempting public regulation with private food quality standards. European Review of Agricultural Economics. 36, (4), 525-539. doi: 10.1093/erae/jbp040>

MOSES, V. 2012. Do European consumers buy GM foods?. JRC SCIENTIFIC AND POLICY REPORTS: 119. Available at: http://rahvatervis.ut.ee/bitstream/1/1969/1/Vokkjt2008.p $\underline{\mathrm{df}>}$

MOSES, V. and BROOKES, G. 2013. The world of "GM-free". GM crops \& food: Biotechnology in Agriculture and the Food Chain. 4, 135-142. doi: 10.4161/gmcr.25992>

NON-GMO PROJECT 2015. The "Non-GMO Project Verified" Seal. Available at: http://www.nongmoproject.org/learn-

more/understanding-our-seal/>

PASSUELLO, F., BOCCALETTI, S. and SOREGAROLI, C. 2013. Managing "GM-free" Food Supply Chains in Italy: Insights from a Case Study, 17th ICABR Conference: "Innovation and Policy for the Bioeconomy", Ravello, Italy.

PUNT, M.J., VENUS, T.J. and WESSELER, J. forthcoming. Case Study: "GMO-free” labelled dairy products in Germany. EuroChoices.

RÉPUBIQUE FRANCAISE 2012. Décret n 2012-128 du 30 janvier 2012 relatif à l'étiquetage des denrées alimentaires issues de filières qualifiées «sans organismes génétiquement modifiés». Available at: http://www.legifrance.gouv.fr/affichTexte.do?cidTexte=J ORFTEXT000025241412\&categorieLien=id>

SEIFERT, F. 2002. Gentechnik - Öffentlichkeit Demokratie: Der österreichische Gentechnik-Konflikt im internationalen Kontext. Profil Verlag, Munich, Vienna.

SPELSBERG, G. 2013. Oettinger ohne Gentechnik. Ein Billig-Bier will gut sein. Available at: http://www.gutegene-schlechte-gene.de/oettinger-bier-ohne-gentechnik/> SPENCE, M. 1973. Job market signaling. The Quarterly Journal of Economics. 87, (3), 355-374. Stable URL: http://www.jstor.org/stable/1882010

VANDEMOORTELE, T. and DECONINCK, K. (2014) When are private standards more stringent than public standards?. American Journal of Agricultural Economics. 96, (1), 154-171. doi: 10.1093/ajae/aat064>

VENUS, T.J., KALAITZANDONAKES, N. and WESSELER, J. 2012. Ist das Angebot von Nahrungsmitteln "Ohne Gentechnik" wirtschaftlich nachhaltig? Vierteljahrshefte zur Wirtschaftsforschung. 81, (4), 93-110. doi: 10.3790/vjh.81.4.93>

VIGANI, M. and OLPER, A. 2014. GM-free private standards, public regulation of GM products and mass media. Environment and Development Economics. 19, (6), 743-768. doi: 10.1017/S1355770X13000673>

VLOG, 2015. Auch Lidl mit "Ohne Gentechnik"-Milch. Available at: http://www.ohnegentechnik.org/aktuelles/nachrichten/20 15/juni/auch-lidl-mit-og-milch/>

VON SCHLIPPENBACH, V. and TEICHMANN, I. 2012. The strategic use of private quality standards in food supply chains. American Journal of Agricultural 
Economics. 94, (5), 1189-1201. doi: Versorgung mit GMO-freiem Soja nicht mehr 10.1093/ajae/aas070> sichergestellt, Berlin. Available at: WESSELER, J. 2014. Biotechnologies and agrifood strategies: opportunities, threats and economic implications. Bio-based and Applied Economics. 3, (3), 187-204. doi: 10.13128/BAE-15017>

WINSTON, M. 2002. Travels in the Genetically Modified Zone. Cambridge: Harvard University Press.

ZDG, Z.d.D.G.e.V. 2014. Deutsche Geflügelwirtschaft sucht neue Alternativen in der Futtermittelproduktion:

$\frac{\text { http://www.presseportal.de/pm/32363/2667518 }}{\text { ZILBERMAN, D., KAPLAN, S., KIM, E. and }}$ WATERFIELD, G. 2014. Lessons from the California GM Labeling Proposition on the State of Crop Biotechnology. Handbook of Agriculture, Biotechnology, and Development. Ed. S.J. Smyth, P.W.B Phillips, and D. Castle, Chapter 34. Cheltenham: Edward Elgar. 